\title{
Some Notes on the Gresham's Law of Money Circulation
}

\section{Amelia Carolina Sparavigna ${ }^{1}$}

\author{
${ }^{1}$ Department of Applied Science and Technology, Politecnico di Torino, Italy
}

\begin{abstract}
The Gresham's Law is among the most known laws of economic science. In its popular version, the law is telling that when a government overvalues one type of money and undervalues another, the undervalued money disappears while the overvalued money floods into circulation. Named after Thomas Gresham, a financier of Tudor dynasty, this law was stated by Nicole Oresme and Nicolaus Copernicus. Here we discuss it and follow its long history.
\end{abstract}

Keywords: Money Circulation, Commodities, Legal Tenders

\section{Introduction}

One of the laws governing the circulation of money is usually known as the Gresham's Law, named after Sir Thomas Gresham (1519-1579), an English financier of Tudor dynasty. In fact, this law had been previously discussed, in the fourteenth century by Nicole Oresme [1], and then by Nicolaus Copernicus in a treatise of 1526 , and, in spite of its name, it was never explicitly stated by Gresham. However, the awareness of it is implicitly supposed in his actions as adviser of Queen Elizabeth the First.

In Reference [1], the author, Thomas Balch (18211877), an American historian best known for his work on the American Revolutionary War and considered the father of international arbitration, aimed popularizing the Gresham's Law and its history, writing on it after consulting the original manuscripts of Oresme and Copernicus edited by Louis Wolowski in 1864 [2], and the life of Sir Thomas Gresham, written by John Burgos and printed in 1839 [3]. Balch is writing that the Gresham's Law is "among the most certain laws known to economic science", and that its immutable operation had been thoroughly demonstrated in all ages of humanity. Let us discuss this law and follow its long history, using the Balch's text for the works of Oresme and Copernicus. However, first of all, let us define some economic terms concerning the money circulation.

\section{Gresham's Law}

This law is an economic principle that it is usually stated in the following manner: when a government overvalues one type of money and undervalues another, the undervalued money disappears from circulation into hoards, while the overvalued money floods into circulation [4]. It seems that it was in 1858 that the expression "Gresham's Law" was coined for it by Henry Dunning Macleod [5]. Sometimes it is also named after Copernicus. However, this law was stated previously in the fourteenth century by Nicole Oresme; for this reason we find it named "Law of Oresme,
Copernicus and Gresham" in the title of Reference [1]. In the following, we will use its traditional name of "Gresham's Law".

To understand this law, we need to define what commodity money is and what adjectives "undervalued" or "overvalued" mean. Commodity money is medium of exchange whose value comes from a commodity of which it is made. Therefore, commodity money consists of objects that have intrinsic value as well as value in their use as money [6]. Examples of commodity monies include gold, silver, salt and cocoa beans in ancient America. Besides these monies having an intrinsic value, legal tenders exist, which are a medium of payment stated by law. For instance, non-precious metal coins or paper currency are legal tenders. Usually, a legal tender has an intrinsic value which is lower that its face value, which is the value printed on it. In the case of paper currency, the banknote does not possess any intrinsic value.

The circulation of both commodities and legal tenders requires a legal-tender law, telling that the two forms have the same face values for economic transactions. Therefore, it can happen that in the same country, there are circulating artificially overvalued monies, which have an intrinsic value lower than their face value, and undervalued monies, having an intrinsic value higher that their face value. When both monies are accessible at the same time, the Gresham's law is usually assumed to govern their circulation.

\section{Fiat money}

Sometimes, a legal tender is also defined as "fiat money". The term derives from the Latin "fiat", that is, "it shall be", therefore "it shall be money". As told in [7], gold reigned supreme as the "traditional standard of value" from the earliest use of coins (about 700 BC). But money changed its face; besides the metal coins, paper money evolved alongside it, eventually displacing gold and silver over the last century. Paper money had been originated in the China of third 
century BC, but accounts of it first reached Europe through Marco Polo's reports of the Kublai Khan's money in the thirteenth century AD. Marco Polo, in the Milione written in Old French by Rustichello da Pisa, describes the production of paper money from the bark of mulberry trees, which were also the food source for the silk worm, the engine of ancient Chinese commerce [7]. As remarked in [7], Kublai Khan's paper money exemplifies what economists today call "fiat money", money which is not linked to any commodity, but simply declared by a sovereign to constitute legal currency. "While the value of modern fiat money is substantially a function of market perception, Kublai Khan took a far more direct approach, simply decreeing that anyone within his kingdom refusing to accept this money would be executed (as would forgers)" [7]. And Marco Polo stressed the fact that all peoples who were subjected to Kublai's rule were willingly accepting these papers in payment.

In Europe paper money emerged and accompanied the rise of modern banking systems and debt markets [7]. Negotiable "bills of exchange" arose during the Middle Ages to facilitate trade among merchants, permitting those selling on credit to "either use the bill as a means of payment in its own right or obtain cash for it at a discount from a banker willing to act as broker, the core business of the Medici in fifteenth-century Florence" [7,8]. Before the Medici, this was a business of the Knights Templar too; these knights are credited as the inventors of banking [9]. However, in Europe, the value of the "fiat money" long remained linked to metals.

\section{Good and bad money}

The Gresham's law applies when we can have "good" and "bad" money at the same time. "Good" money is money that shows little difference between its face value and its commodity value, for instance, the intrinsic value of the metal of which it is made. On the other hand, "bad" money is money that has a commodity value considerably lower than its face value and is circulating as a legal tender. In Gresham's time, bad money included any coin that had been debased or counterfeit.

A debasement of coins can be operated by governments or individuals. Debasement was often used by governments in order to inflate the amount of currency in circulation. Typically, this was obtained when some of the precious metal was replaced by a cheaper metal when the coin was minted. In this case, a legal tender law is used to hold the face value of the debased coins at a higher level. For example, the intrinsic value of the Denarius, a currency of the ancient Rome, decreased over time as the Roman government altered both the size and the silver content of the coin. Originally, the silver was nearly pure, weighing about 4.5 grams. During the Julio-Claudian dynasty, the Denarius contained approximately 4 grams of silver, and then was reduced to 3.8 grams under Nero. The Denarius continued to shrink in size and purity until it was replaced by a new coin [10]. The last issuance of a Denarius occurred in bronze form, between AD 270 and 275.

When debasement is made by individuals, usually by clipping or scraping off small amounts of the precious metal, this is for the personal profit. The clipping consists in shaving metal from the coin's circumference. This explains the fact that many coins have their rim marked with stripes, text or some pattern that would be destroyed if the coin were clipped. Although the metals in current coins are not intrinsically valuable, milling is used as a deterrent to counterfeiting or simply for decoration. Probably the first examples of coins with marks on the rim to avoid clipping are the Denarii Serrati of the Roman Republic (Figure 1). Other examples of bad money include counterfeit coins. In the case of clipped, scraped, or counterfeit coins, the commodity value was reduced by fraud.
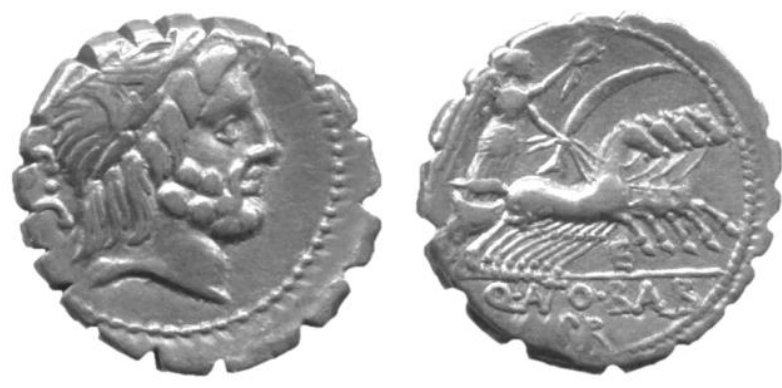

Figure 1 - Denarius serratus of Quintus Antonius Balbus (c. 82-83 BC). Courtesy: Wikipedia.

To maintain the value of the currency, a government can use a recoinage. For instance, in 1696, the British Government decided a "Great Recoinage" in order to replace the silver coins circulating in the country in that period. The silver coins, hand struck prior to 1662 , had been clipped around the edges and their value so reduced that they were no longer a viable tender, especially abroad [11]. Moreover, the machine struck silver coins produced by the Royal Mint in the Tower of London after 1662, protected from clipping by engraving, were forged. By 1696, forged coins constituted about $10 \%$ of the nation's currency [11].

The currency had a third problem too: its value like silver bullion in Paris and Amsterdam was greater than the face value in London, and thus vast quantities of coins were melted and shipped abroad. One of the greatest scientists of all times, Sir Isaac Newton, warden of the Royal Mint, was involved in these financial problems. Newton's chemical and mathematical knowledge proved of great use in carrying out the Great Recoinage, a process that was completed in about two years [11].

Old coin was taken back by weight rather than face 
value. But the recoinage was not a financial success, because production tailed off by 1698 [11]. Moreover, it was impossible to maintain a system based on both gold and silver, because of the variation in the bullion values of these metals. In practice, a silver coin was worth more in mass than in face value [12], and the only way to maintain silver in coins was to reduce the silver content to have a face value higher than its bullion value. And this happened with the Great Recoinage of 1816 [11].

\section{Hoarding}

Another problem concerning the "good" money is its disappearance from circulation in private hoards. This usually happened for gold and silver coins. Let us consider some recent examples, one from Italy. The Italian Republic coined some silver coins with a face value of 500 Lire, from 1958 till 1967. They were quite beautiful coins in three series, named "Caravelle", "Unità d'Italia" and "Dante". In 1966, Italy started to issue a banknote with the face value of 500 Lire too. The government stopped the coinage of silver coins after 1967, because of two facts. One was the cost of silver, and the other the phenomenon of "tesaurizzazione". That is, these silver coins were collected into private hoards, disappearing from circulation. This episode is in agreement with the Gresham's Law: people used "bad" money, the banknotes, in daily transactions instead of "good" money, the silver coins which were collected in hoards.

Silver coins circulated in Canada (until 1968) and in the United States (until 1964 for dimes and quarters and until 1969 for half-dollars). These countries debased their coins, as the market value of silver rose above that of the face value [4], and the silver coins disappeared from circulation as citizens retained them, using the newer coins in daily transactions. Moreover, some individuals were motivated to melt them down and sell the metal for its higher intrinsic value. The 1965 United States half-dollar coins contained 40\% silver; in previous years, these coins were $90 \%$ silver. "With the release of the 1965 half-dollar, which was legally required to be accepted at the same value as the earlier $90 \%$ halves, the older $90 \%$ silver coinage quickly disappeared from circulation, while the newer debased coins remained in use. As the price of bullion silver continued to rise above the face value of the coins, many of the older half dollars were melted down. Beginning in 1971, the U.S. government gave up on including any silver in the half dollars, as even the metal value of the $40 \%$ silver coins began to exceed their face value" [4].

Private hoards are an ancient phenomenon, as archaeology is often demonstrating. It happens that hoards, usually created with the intention of later recovery by the hoarder, survive and are uncovered in particular by the metal detector hobbyists. In fact, hoards provide a useful method to science for dating artifacts and are considered an indicator of the relative degree of unrest in ancient societies, becoming a snapshot of the period of time during which they have been created [13]. One of the most famous hoards of Roman gold and silver coins was found in the village of Hoxne in Suffolk, England, in 1992. The coins of the hoard date it after AD 407, which coincides with the end of Britain as a Roman province [14].

About the ancient hoards, we can consider what Reference [15] is telling too. If they hadn't have been lost for several reasons, probably they would have been put back into circulation and the coins would have ended up at the mint. It is therefore quite probable that "most silver ultimately found its way back to the mint". Reference [15] is also comparing the ancient phenomenon of hoarding to what happened in the year 1947, when silver coins of the United Kingdom were replaced by cupro-nickel coins, because the government needed the silver to help pay for war debts. "People noticed the change and started to put their spare silver coins into jars. By the time the silver had disappeared from circulation, scrap dealers were offering to buy these 'hoards'. Inflation was not a factor here and the price of silver was much the same in 1947 as it was in 1946. Therefore if it had been worthwhile collecting silver coins for their absolute bullion value 'after debasement', then it would have been worthwhile before. It was simply the sudden appearance of the "bad" money and the perceived difference in value that triggered hoarding, regardless of the profit, or even loss, in doing so" [15]. In fact, people retained coins or spent coins according their relative, not absolute, value: eventually, almost completely copper coins superseded the silver coins. And this was the end of the silver coinage [15].

Summarizing, when we have circulating currency consisting of both "good" and "bad" money, both forms having an equal value stated by a legal-tender law, the circulation can become dominated by the "bad" money. This happens because people spending money will hand over the "bad" coins rather than the "good" ones, keeping the "good" ones for themselves [4].

\section{Ancient world}

Let us start the history of the Gresham's Law following the text written by Balch [1]. We have already discussed on debasement of the silver Denarius in the Roman Empire. But this phenomenon, as Balch is telling, existed in the ancient Greece too. There is ample proof of it in the play entitled "The Frogs" of Aristophanes. In that play, the foremost comic dramatist of Greece places in the mouths of the chorus these lines: "Oftentimes have we reflected on a similar abuse, In the choice of men for office, and of coins for common use; For your old and standard pieces, valued and approved and tried Here among the Grecian nations, and in all the world beside, Recognized in 
every realm for trusty stamp and pure assay, Are rejected and abandoned for the trash of yesterday; For vile, adulterate issue, drossy, counterfeit and base, Which the traffic of the city passes current in their place". Balch is also giving another translation of this passage, rendered in the following way: "The freedom of the city has often appeared to us to be similarly circumstanced with regard to the good and honourable citizens as to the old coin and the new gold. For neither do we employ these at all, which are not adulterated, but the most excellent, as it appears, of all coins, and alone correctly struck and proved by ringing everywhere, both among the Greeks and the barbarians, but this vile copper coin, struck but yesterday and latterly with the vilest stamp".

In the above quotations it is distinctly shown that at Aristophanes' time the better coins were driven out and replaced by pieces of inferior value. In fact, Aristophanes was describing the Gresham's Law of money. We can infer from Aristophanes' play that "the Grecian States passed through the ups and downs of a change in the standard of value caused by a debasement of the currency. The same state of affairs continues Balch - existed among the Romans, and the amount of benefits and evils that obtained in the reign of each Roman Emperor can in a measure be judged by the greater or less purity of the coinage issued in their respective reigns. The experiences of the Ancient World with money as the mechanism of exchange were largely unknown to the peoples of the Middle Ages, and they had to discover for themselves at a great and bitter cost that any attempt to debase the currency only results in the good money disappearing from circulation to the ruin of the commonwealth and of its inhabitants, especially of the poorer members" [1].

Balch, such as other scholars, is starting the history of the Gresham's Law with Aristophanes. However, Wikipedia is reporting that references to this law exist in more ancient texts. According to Ben Tamari, the currency devaluation phenomenon was already recognized in ancient sources such as the Bible, the Mishna and Talmud [4].

\section{Three men exercising three different callings}

In [1], Balch is telling that "three men, exercising three different callings but all three profound students, and two of them ranking among the scholars of the world, in three different countries, in three distinct periods of time, discovered independently of one another and explained to their respective sovereigns that when into the currency of a country a poorer or cheaper money is injected by the side of a better which is the standard of value, the certain and immutable result will be that the currency of the realm will be debased to the standard of the poorer money". These three men were Nicole Oresme, Bishop of Lisieux in Normandy, who stated this law for Charles the Fifth of France, Nicolaus Copernicus of Thorn in Prussia, the discoverer of the
Copernican theory of Astronomy, who expounded this same law of the currency for Sigismund the First of Poland, and Sir Thomas Gresham, who explained it to Elizabeth of England. "It is proper then that in honor of these three discoverers of an economic truth that is a precious thing for humanity to know, that this law should be called the Law of Oresme, Copernicus and Gresham" [1].

Nicole Oresme and Nicolaus Copernicus, for their pioneer work in the exposition of the rules that govern money as the medium of commercial exchange, have been described by the Scottish economist Henry Dunning Macleod (1821 - 1902) as the "Castor and Pollux" of Monetary Science [1]. Oresme and Copernicus delved into the past experiences in the matter of money of their respective countries, and probably made use of much of what the Greek and the Roman publicists had said on the subject. The light shed by them on the functions of currency helped people through the following financial measures, taken by Charles the Fifth of France and Sigismund the First of Poland [1]. "Sir Thomas Gresham likewise, through Elizabeth of England, aided the human race to derive the advantages that are conferred upon society by an honestly maintained measure of value": these are the Balch's conclusions, on the studies and efforts of these men, to acknowledge the mechanisms of currency circulation and the effects of its debasement, and to find the remedies.

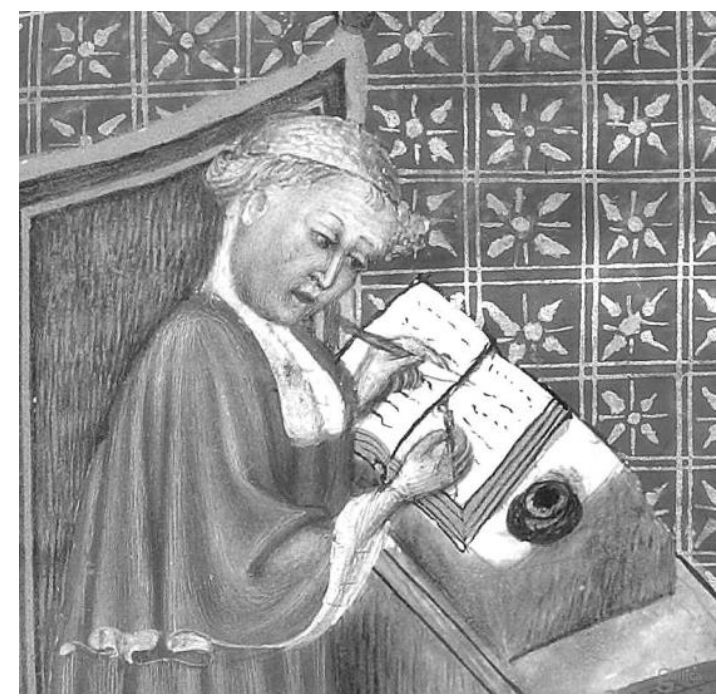

Figure 2 - Nicole Oresme, protrayed in his manuscript Traité de la sphère, dated 1400-1420, at the Bibliothèque Nationale de France, available at gallica.bnf.fr

\section{Nicole Oresme}

The importance of the economic work of Nicole Oresme was first revealed to the world at large in 1862 by William Roscher, Professor of Political Economy in the University of Leipzig. Oresme's master work, 
Tractatus De Origine, Natura, Jure et Mutationibus Monetarum, was often referred to before that time, but, before Roscher's analysis, the examiners of Oresme's treatise "failed to grasp its real importance" [1]. "When, however, it came under the eye of Roscher, a trained economist, he saw at once the profound significance of the work". Under the title of "A Great French Economist of the Fourteenth Century", Roscher called the attention of the world to Oresme's treatise on money. Two years later, Louis Wolowski signalized the work of this medieval scholar too $[1,16]$.

Nicole Oresme (1320-1325, 1382) was a significant philosopher of the later Middle Ages (Fig.2). Besides those on economics, he wrote influential works on mathematics, physics and astronomy, philosophy and theology. He was Bishop of Lisieux and a counsellor of King Charles V of France, and probably one of the most original thinkers of the fourteenth century. Nicole Oresme was by birth a Norman, of the village of Fleury-sur-Orne in the vicinity of Caen, in the diocese of Bayeux. Practically nothing is known concerning his family. Oresme attended the royally sponsored and subsidized College of Navarre, an institution for students too poor to pay their expenses while studying at the University of Paris; this fact makes it probable that he came from a peasant family [17]. At the University, Oresme was reputed to be the most able and learned in his knowledge of the sciences and the fine arts. He studied the "Artes", together with Jean Buridan, and there he became "Magister Artium" [17].

In 1348, he was a student of theology in Paris. In 1356, he received his doctorate and in the same year he became Grand Master of the College of Navarre. In 1364, he was appointed Dean of the Cathedral of Rouen. Around 1369, he began a series of translations of Aristotelian works at the request of the king, who granted him a pension in 1371 and, with the royal support, was appointed bishop in 1377. In 1382, he died in Lisieux. [17]. He translated at the request of Charles the Fifth the Bible, in order that this vernacular version might be opposed to that of the Waldensians [1].

"When Charles the Fifth succeeded to the throne of his ancestors, the French, crushed by what was for those times an enormous debt, were groaning under the weight of the accumulated mismanagement of previous rulers, and the 'royaume des lys' had shrunk to small proportions before the English invasion, and was fast disappearing in misery and anarchy. Owing to the capture of Charles's father, King John, by the English, Charles was called upon to act as regent. During those years he learnt much which later as king he put to valuable practical use. Reigning from 1364 to 1380 under the title of Charles the Fifth, he was, for his able management of the affairs of his kingdom, justly surnamed the Wise. This honorary title, Charles the Fifth, who was a capable and sagacious man, was entitled for in great measure to the fact that he surrounded himself and relied upon the services of men of first rate ability who had strengthened their natural capacities by hard work, such generals as the Breton, Bertrand du Guesclin, such scholars as the Norman, Nicole Oresme. It was Charles the Wise, too, who, in beginning the first collection of manuscripts in the Louvre, that afterwards became the Bibliothèque Royale, then the Bibliothèque Imperiale, and to-day is known as the Bibliothèque Nationale, was the founder of what is today the largest depository of learning in the world" [1].

"The chief cause of the unhappy state in which the French people found themselves when Duc Charles became king in 1364 was in large measure due to the tampering by their rulers with the weight of the value of the coins of the realm. Many of the French kings had thought to raise revenue by forcing their people to accept a debased coinage. Of these royal false coiners, Dante (Alighieri) flays Philip the Fair (1285-1314) in the 'Paradiso' in these words: La si vedra il duol che sopra Senna Induce, falseggiando la moneta, that is, There shall be seen the woe that he shall pour Along the Seine by debasing the coinage" [1]. Dante Alighieri was talking about the king, who debased the money to pay the soldiers for his war against the County of Flanders [18].

Philip IV, called the Fair, was King of France from 1285 until his death. The most notable conflicts of this king include a dispute with Edward I of England and a war with the County of Flanders, which gained temporary autonomy following Philip's defeat at the battle of the Golden Spurs (1302). In 1306, Philip the Fair expelled the Jews from France and, in 1307, annihilated the order of the Knights Templar. In fact, Philip arrested the Jews so that he could seize their assets to accommodate the inflated costs of modern warfare [19]. His financial victims also included the Lombard merchants who had earlier made him extensive loans. They were expelled and their property expropriated. In addition to these measures, Philip strongly debased the French coinage. But this financial crisis led to rioting in Paris which forced Philip to briefly seek refuge in the Paris Temple, headquarters of the Knights Templar [19].

Philip the Fair was substantially in debt to the Knights Templar too. These Knights belonged to a monastic and military order created for the protection of Christian pilgrims in the Latin East. By the end of the thirteenth century, the main activities of the Knights were banking and other commercial services [9,19]. Being the popularity of the Crusades decreased, Philip moved against the Knights and their entire organization, in part to free himself from his debts. Claiming the discovery of a "Templar's heresy", on 13 October 1307, hundreds of Templars were simultaneously arrested to be later tortured [19]. To 
further strengthen the monarchy, Philip aimed controlling the French clergy and entered in conflict with Pope Boniface VIII. This conflict led to move the papal court to Avignon in 1309 [19].

The debasement of coinage was a practice constantly adopted in France. "In addition to debasing the coinage, the French Sovereigns again and again changed the mint price of gold and silver. In the reign of King John the Second, the value of the 'livre tournois' (one of numerous currencies used in France in the Middle Ages) was changed between 1351 and 1360 no less than seventy-one times. And what made the resulting confusion from this unjustified and foolish meddling with the measure of commerce still worse, was that sometimes the value of the 'livre tournois' was raised and sometimes it was lowered. As a result, far from filling the coffers of the king this policy prostrated commerce, and the wealth in the realm of France shrank. When Charles the Fifth, upon his father's death, ascended the throne, he called upon Nicole Oresme, in order that he might reform the coinage of France, to shed light upon the confused currency of the kingdom. And thus it was that Oresme prepared his most important work, already referred to, the first comprehensive treatise upon money, entitled Tractatus De Origine, Natura, Jure et Mutationibus Monetarum" [1].

Oresme, in discussing how money works in the mechanism of exchange, explained to his sovereign that, whenever the public currency was altered in such a way as to have into circulation two moneys, bearing the same face value but in reality having two different values, the money of lower value inevitably drove the money of higher value out of circulation. "For the merchants found it to their advantage either to melt down the pieces of money that contained the higher amount of metal and to sell the bullion by weight or else to export the high weight coins to other lands" [1].

Oresme tells that "the rate of exchange and the price of the moneys must be for the kingdom as a law and a firm ordinance which in no way must alter or change", and, in speaking of the ratio of exchange between gold and silver, he points out that the value or proportion in which those metals are exchanged in their natural state, is the rate of exchange that must be maintained between gold and silver currency. Therefore, if a given amount of gold is worth twenty times as much as silver, then a 'livre' of gold would be worth twenty 'livres' of silver, a 'mark' of gold twenty 'marks' of silver, and so on. But always this proportion, Oresme says, must follow the natural habit or rate of gold to silver, in value.

According to Oresme, the mutations of the currency are of great peril to the national welfare "for the injury which comes by it," he says, "is not so soon felt nor seen by the people, as it would be by another tax, and nevertheless no such nor similar can be more grievous or greater; and, in addition, gold and silver, by such mutations and changes, shrink and diminish in a kingdom, and in spite of all vigilance and prohibition that may be taken, they go abroad where they are accorded a higher value for, by adventure, men carry more voluntarily their moneys to the places where they know these have a greater value" [1].

The words of Oresme on money opened the eyes of the king about the disastrous results to a country whose government attempted to alter the basic value of its currency. "As regent of France during the captivity by the English of his father, King John the Second, who was captured at Poitiers in 1356, Charles had not escaped the prevailing custom among rulers of that epoch to fill the royal purse by debasing the coins of the realm". In the previous century, in 1255 , the States Generals of France, assembled at Paris, obtained from the king, Louis the Ninth, a promise of stable money for the whole Kingdom, "so that the mark of silver should never produce more than six livre tournois. This royal promise was broken again and again by the French sovereigns, and Duc Charles, as regent for his captive father, said the value of the mark should be worth twelve livre tournois. This cutting in half of the measure of value was the signal for the great rising at Paris in 1357 under Etienne Marcel, the Prevost of the Paris merchants, and it was with difficulty that the regent reasserted the royal authority in the city". But the poverty state of the people caused Charles the Wise to follow the advice of sage advisers and set himself to reorganize the finances of France. "The luminous thoughts expressed in the treatise of Oresme he made his own, and during his reign the weight of the gold currency remained a fixed and unchanged quantity, and that of silver was but very triflingly altered. The resulting stability in the value of money, the measure of commercial exchange, re-established the regularity of commercial transactions, and furnished an important element to public prosperity. The resources of the realm augmented and with them the power of King Charles grew" [1].

The Oresme's treatise on money did not become widely known, because this work was written for his king's information, and Gutenberg had not yet made it possible through printing to give them a wide circulation. "The truths that Oresme taught and upon which Charles the Wise acted, to the profit of his kingdom and therefore of himself, became in great measure forgotten" [1]. 


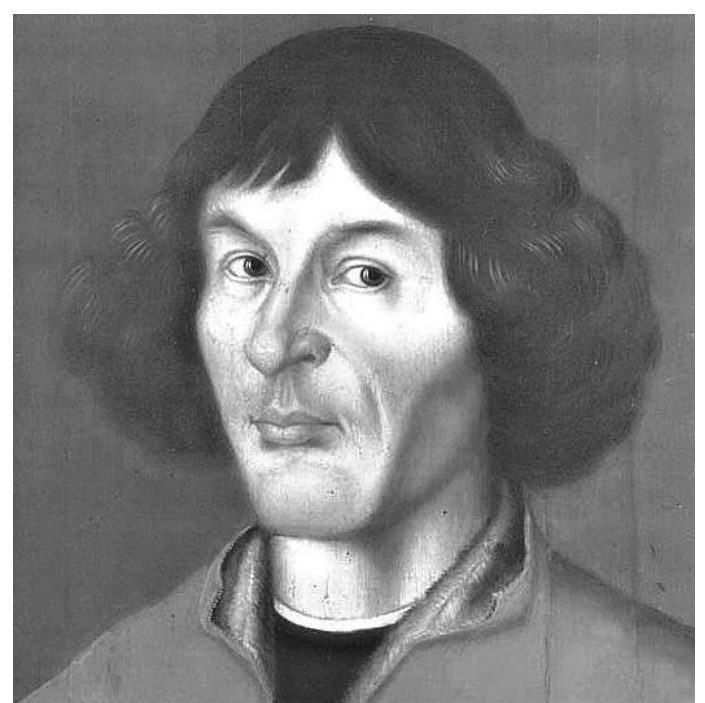

Figure 3 - Nicolaus Copernicus, portrait from Town Hall in Thorn, 1580. Courtesy: Wikipedia.

\section{Nicolaus Copernicus}

A century and a half after Oresme's death, the Gresham's Law was rediscovered a second time. In the year 1526, in a Latin treatise entitled Monetae Cudendae Ratio, written at the request of Sigismund the First, King of Poland, and his Chancellor, Szydlowiecki, Nicolaus Copernicus gave to the world an exposition of some of the economic truths.

Nicolaus Copernicus $(1473$ - 1543, Fig.3) was a mathematician and astronomer who formulated a heliocentric model of the universe. The publication of Copernicus' book, De revolutionibus orbium coelestium, just before his death in 1543, is considered a major event in the history of science. It began the Copernican Revolution and contributed importantly to the scientific revolution [20].

Copernicus was born and died in Royal Prussia, a region of the Kingdom of Poland since 1466. Copernicus had a doctorate in canon law and, though without degrees, was also a physician, classics scholar and translator, and the economist who in 1517 set down a quantity theory of money, a principal concept in economics to the present day [21], besides formulating a version of Gresham's Law [20]. In monetary economics, the quantity theory of money states that money supply has a direct, proportional relationship with the price level. For example, if the currency in circulation increased, there would be a proportional increase in the price of goods [21].

Independently of the work of Oresme, of which the Prusso-Polish scholar knew nothing, Copernicus made clear for his sovereign that two moneys of unequal value could not be kept in circulation at the same time. "Gold or silver," he writes, "marked with an imprint, constitutes the money which serves to determine the price of things that are bought and sold, according to the laws established by the State or the Prince. Money is therefore in some sort a common measure of estimating values; but this measure must always be fixed and must conform to the established rule. Otherwise, there would be, necessarily, disorder in the State: buyers and sellers would at all times be misled, as if the ell, the bushel or the weights did not maintain constant quantity" [1].

Copernicus explains that it would possible to use gold and silver to practice exchanges, because those metals, from the unanimous consent of men, are considered everywhere as precious things, "nevertheless there would be numerous inconveniences to have to carry always weights along, and, all the world not being apt to recognize at the first glance the purity of gold and silver, it is agreed everywhere to have money marked by government with a stamp designed to show how much each coin contains of gold and silver and to serve as a guaranty to public faith". Then he explains how the value of metal pieces is changed and depreciated. "The value of money is depreciated by various causes, either by the change of the name, while the same weight of metal contains a mixture of copper which exceeds the measure desired; or because the weight is wanting, although the mixture has been accomplished in the right proportion; or, what is the worst, because the two vices meet together at the same time. The value of money diminishes of itself by reason of a long service that uses the metal and diminishes its quantity and this reason suffices to cause to be placed in circulation a new money. This necessity is recognized by an infallible sign, when the money weighs notably less than the money intended to be acquired. It is understood that there results a deterioration of the money" [1].

At the time Copernicus prepared his treatise on the money, the Polish Kingdom included Thorn, Danzig, and a large part of Prussia. But a portion of Prussia, including Konigsberg, had been erected, in 1525, by the treaty of Cracow between Sigismund King of Poland and Albert Margraf of Brandenburg, into a hereditary fief for the benefit of the latter and his male descendants. This feudal tenure was subject to the overlordship of the Polish king. Then the two countries were in a sense one. Copernicus, in his treatise, explained to his king what was necessary in order to restore stability to the depreciated Prussian money and then maintain the value of new money on parity so that it could circulate both in Poland and Prussia. He told that it was useless to attempt to introduce into circulation by the side of a depreciated currency one of greater value, because the introduction of a cheaper measure of value by the side of a higher one would drive the former from circulation. A great error is committed introducing new and good money, while old and bad continues to circulate. "By introducing alongside of an old currency, a new currency of less value; this latter does not merely depreciate the old, it drives it away, so to speak, by main force" [1] Then in answer 
to the argument that a depreciated currency helps the poor, he says: "We see nourish the countries that possess a good currency, while those that only have a depreciated one, fall into decadence and decline. ... It is incontestable that the countries that make use of good currency shine in all the arts, have better workmen, and have of everything in abundance. On the contrary, in the States which make use of a degraded money, reigns cowardice, laziness and indolence" [1].

Balch explains that it was necessary to remedy the distress to which Prussia had been brought by falsification and debasement of the currency, and have Prussia and Poland closer together in their commercial relations. For these reasons, it was necessary to coin two moneys of equal intrinsic value, so that they would circulate concurrently in the two lands. One should bear on one side the royal arms of Poland and on the other those of the Prussian land. The other money should likewise have on one side the royal arms of Poland, but on the other the imprint of the prince, that is the effigy of the King. Copernicus pointed out that the first condition to maintain, was that both currencies were under the royal authority and that they were current and accepted in the whole kingdom [1]. "It would be necessary that these two currencies should be of the same degree of fineness, having a similar real value and a similar nominal value, so that, by vigilant care, the State succeeds to maintain perpetually the regulation which it is now question to establish; it does not belong to princes to obtain any profit from the money that they shall coin; they shall add only so much alloy as may be necessary for the difference between the real value and the nominal value to cover the cost of minting, which will avoid the principal attraction to remelt it. ... It would be necessary, at the time of the emission of the new money, to demonetise the old and forbid entirely its use, allowing it to be exchanged at the mints, in the just proposition of the intrinsic value. Otherwise it would be labor lost to wish to re-establish good money; the confusion that would ensue would be perhaps even worse than the actual state of affairs. The old money would crush all the advantages of the new" [1].

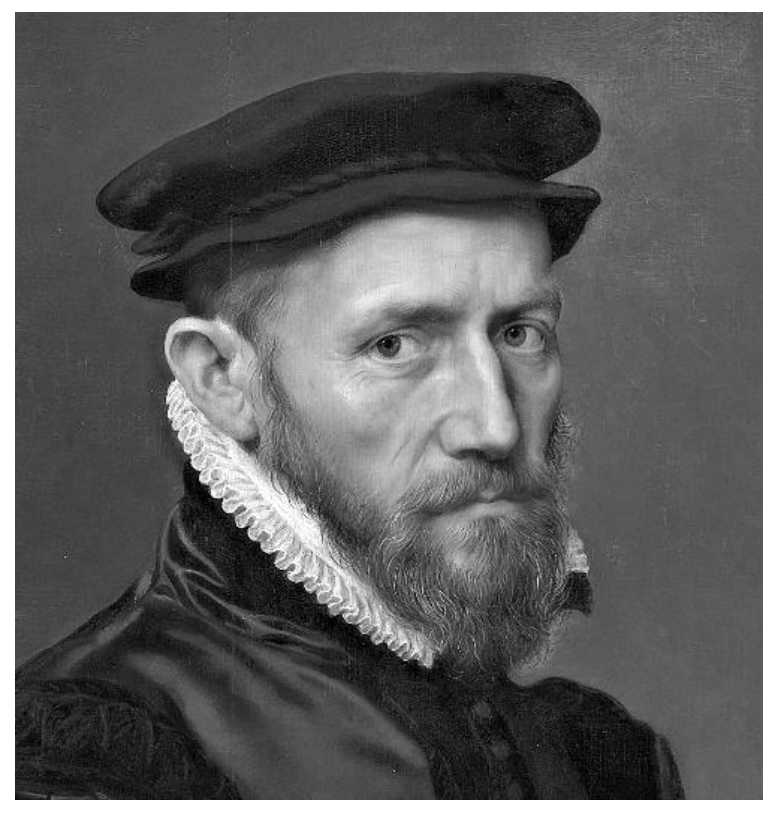

Figure 4 - Portrait of Sir Thomas Gresham by Anthonis Mor. Courtesy: Wikipedia.

\section{Sir Thomas Gresham}

Of a Norfolk family, Thomas Gresham (Fig.4) was born probably in 1519, and died on November 21, 1579. He was educated at Cambridge University, was a Protestant, and all his life took an active part in commercial affairs. In 1566 and 1567 he built the Royal Exchange in London, and founded also the Gresham College [1]. The seven original Professorships of this college were Astronomy, Divinity, Mathematics, Law, Music, Physic, and Rhetoric. This reflects the curriculum of a medieval university with Trivium and Quadrivium Arts. However, this college became a place for new ideas and it played an important role in the Enlightenment and in the formation of the Royal Society. Early famous Gresham College professors have included Christopher Wren, who lectured on Astronomy in the seventeenth century, and Robert Hooke, who was Professor of Geometry from 1665 until 1704 [22].

As told by George Gunton in Reference [23], in political economy, the name of Sir Thomas Gresham stands irrevocably associated with the principle governing the circulation of both "good" and "bad" coins. In [23], it is also remarked that this principle "is doubtless part of a still wider law that dearer tools will not be used to perform a function which can as well be performed by cheaper; and, indeed, of the still wider law, applicable to all values, that people will not pay more for that which they can get for less". At the time Gunton wrote, in 1894, the best account on Sir Thomas Gresham was that given by J.M. Burgos, and entitled Life and Times of Sir Thomas Gresham, published in 1839 [3]. As remarked in [23], in the Burgos' elaborate work, there is no mention of the "Gresham's Law". But, in Burgos' book, there is an appendix reporting 
the letter written by Gresham to Queen Elizabeth, entitled "Information touching the fall of the Exchange", which is cited by Luigi Cossa and others as the source of the so-called "Law of Gresham" or "Gresham Theorem" [24]. This letter shows that an abasement of the coin from six ounces fine to three ounces fine had caused an export of fine coin from the realm. In stating this fact, Gresham implied the law [23].

In the letter to the Queen, Gresham says that, to restore the rate of exchange, it is necessary to suppress the privilege granted to a limited monopoly, known as the Stillyarde, of importing certain kinds of merchandise into England at much lower rates of duty than were paid by other subjects importing like goods. "His mode of restoring the rate of exchange was to rescind the privilege of importing at low duties, and to induce among merchants importing and exporting, a general raising of duties. Thus he restored the credit of the government, and brought coin of pure metal again into the Treasury. It is not expressly taught in this letter that the fineness and purity of the coin must be restored as a condition of bringing it again to par, but the history of the period shows that the sovereign, which in the reigns of Henry VIII and Edward VI (1546-1553) had sunk from 240 grains to 174 6-11 grains, was in fact, in the reign of Mary, restored to 240 grains, and made current for 1L10s. This, after all, left 240 grains to do duty as a pound and a half instead of a pound. This was the period of Gresham's influence, and the event may possibly have been due to his wisdom; but in this letter he seems rather to boast that he has brought the coin of the realm to par by other means" [23].

Let us remember that the Stillyarde, or Stillyard, was a community of foreign merchants, established at London, thus called from the place where they had their residence. The company was created in the year 1215 , or in 1232 , by Henry III in favour of the free cities in Germany, which supported him in his wars against France [25]. However, it is also said that foreign merchants, under this appellation, were fixed at London as early as the Norman Conquest, and that their privileges were considerably enlarged by Henry III. "In fact, it had rendered itself mistress of all the English manufactories, particularly those of cloth, which it was allowed not only to sell throughout the kingdom, but also to transport abroad" [25]. These privileges were revoked by Edward VI, in 1552, restored by Queen Mary in 1554, and soon after revoked. In the year 1578, their ancient immunities were totally and finally abrogated by Queen Elisabeth; and in 1597 their house was shut up and its German inhabitants sent away.

\section{The Letter to Queen Elisabeth}

Upon the accession of Queen Elizabeth in 1558 Gresham was presented to her. Then he wrote a Letter to the Queen, which is headed, "Information of Sir
Thomas Gresham, Mercer, touching the fall of the exchange, MDLVIII, 1558". Here the letter is the following, written in the English of the Tudor Period.

"To the Quenes most excellant maiestye, Ytt may pleasse your majesty to understande, thatt the firste occasion off the fall of the exchainge did growe by the Kinges majesty, your latte ffather, in abasinge his quoyne ffrome vi ounces fine too iii ounces fine. Wheruppon the exchainge fell ffrome xxvis.viiid. to xiiis.ivd. which was the occasion thatt all your ffine goold was convayed out of this your realme. Secondly, by the reason off his wars, the Kinges majestie ffell into greatt dept in Flanders. And ffor the paymentt therof thay hade no other device butt paye itt by exchainge, and to carry over his ffine gowlde ffor the paymentt of the same. Thirdly, the greatt ffreadome off the Stillyarde and grantinge of licence ffor the carringe off your woll and other comodytes ought off your reallme, which is now on off the cheffest pointes thatt your majestie hathe to forsee in this your comon well; thatt you neavir restore the steydes called the Stillyarde againe to ther privelydge, which hath bine the cheffest poynte off the undoinge off this your realme, and the marchants off the same. Now, for redresse off thes thinges, in an.xvcli. (1551) the Kinges majestie, your latte brother, callide me to bee his agentt, and repossid a more trust in me, as well ffor the paymentt off his depttes beyond the seas, as ffor the ressynge off the exchainge, - beinge then at xvs. and xvis. the pounde; and your mony corrantt, as itt is att this presentt, beinge nott in vallew xs. First, I practized with the Kinge and my lorde of Northomberlande to overthrow the Stillyarde, or else ytt coulde nott be brought to passe, ffor thatt they woold kepp downe the exchainge by this consideration; wher as your owne mere marchantes payeth outtwardes xivd. upon a cloth custome, thay paye butt ixd. ; and like wisse, ffor all such wairs as was brought into your reallme, your own mere marchantes payeth xiid. upon the pounde, the Stillyarde payd butt iiid. upon the pounde, which is vs. difference uppon the hundreth; and as they wear men thatt raine all uppon the exchainge ffor the byenge of ther comodytes, whatt did thay passe to give a lowar price then your owne marchantes, when thaye gotte vl. in the hundreth by your custome; which in processe off time would have undone your whole reallme, and your marchantes of the same" [23]. The remainder of the letter expresses a strong desire that the rate of exchange be kept up, and that to this end exemptions from duties be abolished; but does not advise a retirement of the overvalued coinage or the substitution of a new coinage.

In [26], de Roover discussed the misattribution of the Law to Gresham remarking "Gresham, consequently, does not state that bad money necessarily drives out good. On the contrary, he shows that bad money may be greatly overvalued and will not drive out the better coins, provided that the baser coins are issued only in 
limited quantity and not in excess of the needs of trade".

\section{John Hales}

According to [23] and [24], Elizabeth Lamond discussed in a paper published in 1891 [27], that, about 1549, John Hales in a work having the form of a dialogue, had made a very clear statement of the law, which Sir Thomas Gresham, nine years later, more nearly assumed as a fact than stated as a doctrine. John Hales (c.1516 - 1572) was a writer, administrator and politician during the Tudor period [28]. Hales may have spent some time at Oxford, but was largely a selftaught scholar of Greek, Latin and Hebrew. By 1535, he was in the service of Thomas Cromwell. During the period of the dissolution of the Monasteries, Hales purchased a priory in London and a monastery in Coventry. Hales converted part of the monastery into a residence, and set up a free grammar school in what had been the choir. When King Edward VI came to the throne in 1547, Hales became a Member of Parliament and supported the economic policies pursued by the young King's uncle, Protector Somerset. He was particularly opposed to the enclosure of land [28]. When Somerset fell from power in October 1549, Hales was imprisoned in the Tower, likely as a result of his support for Somerset's policies. He was released in 1550, and on 2 February 1551 leaved England. So it was during these years that Hales might have arrived at his statement of the Gresham's Law.

Probably, as observed in [23], this happened through Hales' familiarity with the classics. In fact, as we have seen, the law is stated in Aristophanes' plays. "It seems to have been so familiar and trite to the ancient mind, that it was even used to illustrate the analogous fact that in democracies, and under the system of popular elections, bad men drive out the good in the chase for office, very much as, under the law now attributed to Gresham, bad coins drive out the good" [23]. What Aristophanes wrote is a "little gem, coming down to us from the period of the highest development of Greek thought and art", and it "shows that the period of Sir Thomas Gresham could only in this respect restore an ancient thought. It could not originate. Sir Thomas Gresham sufficiently apprehended the delicate principle in the movements of commerce with which his name stands indelibly associated to deserve the niche in which history has placed him" [23].

The John Hales' work is quite interesting, according to Luigi Cossa [21]. It is a dialogue carried on, under the general supervision of a lawyer, by a landlord, a shipowner, a shop-keeper, and a hatter. "Here we have a multitude of facts derived from fresh observation, and the result is a most vivid picture of conflicting views and points of view in regard to the revolution in prices. Lively complaints of its disastrous consequences, together with the most irreconcilable theories of its causes and of the remedies for which it calls, are also given". This dialogue was published in 1581 by W.S., identified with William Stafford (1554-1612), with the title "A compendious or briefe examination of certayne ordinary complaints" [25,29,30]. A second edition, which appeared in the same year, was reprinted in 1751 [30]. It was even attributed the authorship to Shakespeare.

Cossa tells that Stafford was probably only its publisher, and chiefly responsible for certain omissions: among other points left out in Stafford's publication, there was the clear statement of the socalled law of Gresham. Stafford also made additions of his own. Hales, in the pamphlet as he wrote it, discussed the uttering of debased coinage and the withdrawal from cultivation of various lands which were used for grazing though they had formerly yielded crops of grain. Hales proposed to remedy the existing state of things by tariff reforms, such as a heavy impost on the exportation of wool, and by free trade in corn [25]. Elizabeth Lamond determined the conclusive refutation of Stafford's authorship, discovering two extant manuscripts of the work, one belonging to William Lambarde, and the other formerly belonging to the Earl of Jersey and then to the Bodleian Library. A third, which escaped her notice, it is among the Hatfield MSS [29]. The Lambarde manuscript was written not later than 1565; from internal evidence it is evident that the work was written in the summer of 1549, and it gives an invaluable account of enclosures, debasement of the coinage, and other causes of social distress during the reign of Edward VI. The Lambarde manuscript was published by Lamond in 1893 with introduction, appendices, and notes.

\section{Controversies on the Gresham's Law}

Reference [31] is discussing the law, starting from the following question: "if a mint issues two distinct types of silver dollars one containing, say, half as much silver as the other, will both coins be used as medium of exchange?" As we have seen previously, using the popular version of the law, accepted and frequently proposes in economics, the answer is no. Only one coin will circulate because bad money drives out good. In this case, the lighter silver dollar circulates and the good will be hoarded. But, as told in [31], someone could tell that to determine what happens to the two silvers dollars we need more information. In fact, a version of the Gresham's Law exists, which includes an important qualification. According to this version, bad money drives out good, when the face values of the two monies differ from their market price. The good money disappears because selling it at its intrinsic value is more profitable that using it at face value as a medium of exchange.

However, according to the authors of [31], A.J. Rolnick and W.E. Weber of the Federal Reserve bank of Minneapolis, neither of the versions, the popular and 
the qualified, is adequate to answer the question about silver dollars. The short popular version is contradicted by several historical facts, where the authors find that bad money failed to drive out good money (however in [32], Greenfield and Rockoff dispute these examples). Moreover, in [31], it is told that the qualified version of the law, as given in Ref.33 for instance, is not adequate either, because there are no evidence that "a fixed rate of exchange ever existed, and that is not surprising since it is hard to believe it ever could exist" [31]. Therefore the abovementioned qualifier is not able to reinstate the law. Since this qualifier fails, Rolnick and Weber proposed a new qualifier to Gresham's Law, "one that depends on fixed transaction costs rather than a fixed rate of exchange. Bad money will drive good money out of circulation - are the authors arguing but only when use of the good money at its market (nonpar) price is too expensive". Generally, since small change is expensive to use at a nonpar price, it is expected that the small denominations of the money undervalued at the mint become scarce while large denominations circulate at a premium [31].

Weber continued the analysis of the Gresham's Law in [34], where the authors are proposing a model of commodity money and debasement. The authors developed it to analyze the following two questions motivated by issues in monetary history: what are the conditions under which Gresham's Law holds? and, what are the mechanics of a debasement? Their model contains light and heavy coins, imperfect information, and prices determined via bilateral bargaining. After solving the model, the researchers found that there can be equilibrium with both coins in circulation. Since coins may trade "by weight" or "by tale", the extent to which Gresham's Law holds is discussed in [34] in the various cases.

\section{Asymmetric information}

As remarked in Reference [35], the applicability of the popular version of Gresham's Law is a matter of considerable controversy. This controversy exists because there can be two circulations of money. One is defined the "circulation by weight", where different types of coins are circulating at an exchange rate reflecting their intrinsic values; the other is the "circulation by tale", where exchange rate between the two monies is fixed by means of legal-tender laws, mint exchange policies, or conventions [35,33]. One strand of the literature on the Gresham's Law is arguing on the "circulation by tale", which in [31] is considered as untenable. The other strand of the literature is based on the assumption of asymmetric information about coin values, generating a problem analogous to the Akerlof's lemons problem.

In 1970 the economist George Akerlof published a paper entitled The Market for Lemons: Quality Uncertainty and the Market Mechanism, where it is discussed information asymmetry, which occurs when the seller knows more about a product than the buyer [36]. Akerlof used the example of the market for used cars: in this market, there are good cars, the "cherries", and defective cars, the "lemons", which are so because of several variables, such as owner's driving style, quality and frequency of maintenance and accident history. Usually, the buyer of a used car is not able to evaluate before buying whether the car is a cherry or a lemon, so the buyer's best guess for a given car is that it is of average quality. Accordingly, the buyer will be willing to pay for it only the price of a car of average quality. This means that the owner of a cherry car will be unable to get a high enough price to make selling it worthwhile [36]. Therefore, Akerlof concludes that owners of good cars will not place their cars on the used car market. This withdrawal of good cars reduces the average quality of used cars on the market. As a consequence, the buyers revise downward their expectations for any given car. This, in turn, motivates the owners of moderately good cars not to sell, and so on [36].

This market in which there is asymmetric information with respect to quality shows characteristics similar to those described by Gresham's Law: the bad drives out the good. As remarked in [35], commodity money has always been plagued by problems of asymmetric information because the intrinsic value of coins, and especially their fineness, could be checked only at relatively high costs. In [35], the authors argued that asymmetric information about coin values between trading partners promoted in some cases the working of Gresham's Law. Besides asymmetry, we can also remember the role of the relative, not absolute, value attributed by people to coins, in determining the circulation of money, which has been discussed in Reference [15] about the process of hoarding.

\section{Conclusions}

In this paper we have discussed the Gresham's Law. In particular, we have proposed, following a work written by Thomas Balch, what Oresme, Copernicus and Gresham told on the money circulation. In fact, Thomas Gresham did not explicitly state the popular law that is named after him, that bad money necessarily drives out good money. During the Tudor period, this law was stated in a work written by John Hales, some years before the Gresham's letter to Queen Elizabeth, which is considered the source of the abovementioned law. In the paper, we have also discussed some literature on the validity of this law and the role of asymmetric information in determining the circulation of money.

\section{References}

[1] Thomas Willing Balch, The Law of Oresme, Copernicus, and Gresham, Proceedings of The American Philosophical Society, 1908, Volume XLVII, Philadelphia.

[2] Louis Wolowski, La Question des Banques, 1864, Guillaumin, Paris.

[3] John William Burgos, The Life and Times of Sir Thomas Gresham, 1839, Robert Jennings, London. 
[4] Vv. Aa., Wikipedia, Gresham's Law.

[5] G. Selgin, Gresham's Law, EH.Net Encyclopedia, Edited by Robert Whaples, June 9, 2003, eh.net/encyclopedia/ greshams-law/

[6] A. O'Sullivan and S.M. Sheffrin, Economics: Principles in Action, 2003, Prentice Hall, Page 246.

[7] C.M. Bruner, The Changing Face of Money, Review of Banking \& Financial Law, 2010-2011, Volume 30, Pages 383-406.

[8] N. Ferguson, The Ascent of Money: A Financial History of the World, 2009, Penguin Books.

[9] G.A. Stobbs, Business Method Patents, 2002, Aspen Publishers.

[10] Vv. Aa., Wikipedia, Denarius.

[11] Vv. Aa., Wikipedia, Great Recoinage of 1696.

[12] Ming-Hsun Li, The Great Recoinage of 1696-1699, 1963, Weidenfeld \& Nicholson, London.

[13] E. Oras, Importance of Terms: What is a Wealth Deposit?, Papers from the Institute of Archaeology, University College London, 2012, Volume 22, Pages 61-82.

[14] Vv. Aa., Wikipedia, Hoxne Hoard.

[15] Historia, The Imperial Roman Economy, Hoarding, Gresham's Law and All That, www.forumancientcoins.com/historia/ debasement/economy.html

[16] L. Wolowski, Traictie de la Première Invention des Monnoies de Nicole Oresme, textes français et latin d'après les manuscrits de la Bibliotheque Imperiale, et Traité de la Monnoie de Copernic, texte latin et traduction française publiés et annotés, 1864, Guillaumin, Paris.

[17] Vv. Aa., Wikipedia, Nicole Oresme.

[18] La Divina Commedia di Dante Alighieri col comento del P. Baldassarre Lombardi, Volume III, 1830, L. Ciardetti, Firenze.

[19] Vv. Aa., Wikipedia, Philip IV of France.

[20] Vv. Aa., Wikipedia, Nicolaus Copernicus.

[21] Vv. Aa., Wikipedia, Quantity theory of money.

[22] Vv. Aa., Wikipedia, Gresham College.

[23] G. Gunton, The Social Economist, New York, Institute of Social Economics, July/December 1894, Volume 7, Pages 17-21.

[24] L. Cossa, The Study of Political Economics, 1893, London and New York, Macmillan.

[25] A. Rees, The Cyclopaedia; Or, Universal Dictionary of Arts, Sciences and Literature, 1819, Volume 34, Longman, Hurst.

[26] R. de Roover, Gresham on Foreign Exchange, Cambridge, 1949, Harvard University Press.

[27] E. Lamond, The Date and Authorship of the 'Examination of Complaints' attributed to William Stafford, English Historical Review, 1891, Volume VI, Issue XXII, Pages 284-305.

[28] Vv. Aa., Wikipedia, John Hales (politician).

[29] A.F. Pollard, in Dictionary of National Biography, 1885-1900, Volume 53, Stafford, William (1554-1612).

[30] William Stafford's Compendious Or Briefe Examination of Certayne Ordinary Complaints, by F.J. Furnivall, Published in 1876 by The New Shakspere Society.

[31] A.J. Rolnick and W.E. Weber, Grasham's Law or Gresham's Fallacy?, Federal reserve Bank of Minneapolis Quarterly Review, Volume 10, Issue 1, Pages 17-24.

[32] R.L. Greenfield and H. Rockoff, Gresham's Law in NineteenthCentury America, Journal of Money, Credit and Banking, 1995, Volume 27, Issue 4, Pages 1086-1098.

[33] M. Friedman and A.J. Schwartz, A Monetary History of the United States, 1867-1960, 1963, Princeton University Press.

[34] F.R. Velde, W.E. Weber and R. Wright, A Model of Commodity Money, with Applications to Gresham's Law and the Debasement Puzzle, Federal Reserve Bank of Minneapolis, Research Department Staff Report 215, 1997.

[35] I. Schnabel and Hyun Song Shin, The 'Kipper- und Wipperzeit' and the Foundation of Public Deposit Banks, 2006, annual_mtg_papers/2008/2008_258.pdf

[36] Vv. Aa., Wikipedia, The Market for Lemons. 